\title{
Desrespeito e violência: fazendeiros de café e trabalhadores nepros no Oeste paulista, 1887-1914
}

Karl Monsma

\begin{abstract}
Resumo. O artigo examina relações entre fazendeiros de café e trabalhadores negros após a abolição no município de São Carlos, no Oeste paulista, focalizando sobretudo conflitos violentos registrados em autos penais. Os negros reivindicavam respeito e dignidade, e lutavam para defender seu direito à privacidade; os fazendeiros, ainda ressentidos pela rebeldia dos escravos nos últimos anos antes da abolição, se irritavam com qualquer sinal de desacato dos negros, recorrendo rapidamente à violência para os rebaixar e humilhar, tendência que manifestavam menos nos conflitos com trabalhadores imigrantes. Os imigrantes que compraram fazendas de café ou assumiram posições de autoridade nas fazendas rapidamente internalizaram as mesmas disposições raciais exibidas por seus congêneres brasileiros.

Palavras-chave: Violência racial. Libertos. Fazendeiros de café.

Período pós-abolição. Oeste Paulista.
\end{abstract}

* Professor do Programa de Pós-Graduação em História da UNISINOS.

Anos 90, Porto Alegre, v. 12, n. 21/22, p.103-149, jan./dez. 2005 
Desrespeito e violência: fazendeiros de café e trabalhadores negros...

Hontem as dez. horas, mais ou menos, indo ao cafesal vêr o serviço de apanhação de café e chegando ao eito observou ao escravo Cosme que parecia um escravo novo porque estava quebrando galhos de café e que este escravo respondeo sim senhor, e elle offendido tratando de seguir para diante foi seguro pelas pessoas pelo dito escravo Cosme que o derrubou e imediatamente o escravo de nome Felicio o segurou pelo pescoco e pondo-o de bruco collocou os joelhos nas costas e sendo tambem seguro pelos escravos Crispim e João Criolo, e então fizeráothe os ferimentos com relho, foise e uma cavadeira que arrancarão da mão do feitor [...]. Depois delle depoente prostado no chão todos os demais escravos tomarão parte nas offensas que recebeo; que quando voltou a fazenda veio escorrando sangue, e ficou também com um dente quebrado. ${ }^{2}$

Comparado às fugas em massa que caracterizavam o último ano da escravidão, o espancamento, em julho de 1887, de João Felicio de Godoy, administrador da Fazenda da Horta, no município de São Carlos, São Paulo, pelos escravos do eito talvez pareça insignificante, mas fornece pistas importantes sobre as disposições de pelo menos uma parte dos escravos na véspera da abolição final. $\mathrm{O}$ evento ocorreu no contexto maior de uma luta entre escravos e fazendeiros a respeito do ritmo do trabalho (Machado, 1987, p.97-98). Nas últimas décadas da escravidão, os senhores tentavam enrijecer a disciplina e acelerar a produção, para compensar a alta nos preços de escravos e nos gêneros necessários à sua manutenção. Os escravos, por outro lado, lutavam para conservar uma margem de autonomia e um ritmo de trabalho moderado. Neste caso, porém, os escravos não respondiam a uma tentativa de aumentar a intensidade do trabalho nem a um castigo físico, mas a um insulto. ${ }^{3} \mathrm{O}$ grupo também poderia ter matado Godoy, mas não o fez. Eles largaram o administrador no chão e, depois de algum tempo, ele conseguiu se levantar, montar seu cavalo e voltar à sede da fazenda. Sofreu humilhação, dor, teve um dente quebrado e ficou, pelo menos temporariamente, com "os olhos ingetados de sangue" e dificuldade para enxergar. Tudo sugere que a intenção dos cativos não era matá-lo, mas revidar o insulto a 
Karl Monsma

Cosme e outras ofensas que haviam sofrido desse administrador em outras ocasiões. Ou seja, queriam impor-lhe respeito.

A natureza do insulto proferido pelo administrador João Felicio chama a atenção: parece relativamente brando. Por que Cosme ficou tão ofendido ao ser comparado com um escravo novo? Uma possível interpretação é que os cativos estavam preparados para se rebelarem a qualquer momento, e mesmo uma ofensa pequena serviria como estopim para um motim generalizado. Mas suas ações não sustentam essa versão: além de parar antes de ma-

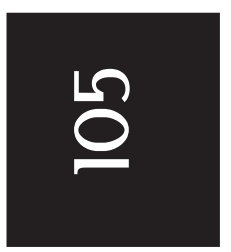
tar o administrador, eles não fugiram. "Escravo novo" nesse contexto não significava africano recém-chegado, figura quase inexistente no Brasil tantos anos depois do fim efetivo do tráfico internacional, mas um escravo novo nos cafezais, como os muitos comprados do Nordeste por fazendeiros paulistas nas últimas décadas da escravidão. Quando Godoy comparou Cosme a um escravo novo, ele não somente disse que Cosme não sabia apanhar os frutos direito, mas também invocou a divisão entre os escravos estabelecidos da zona e os novatos de outras regiões, distinção que, como mostra Hebe Mattos, influenciava fortemente nas chances de casar-se, de morar em casas próprias, de ganhar diretos informais ao usufruto de terras, e de integrar extensas redes de relações com outros cativos e negros livres. ${ }^{4}$ É muito provável que às diferenças materiais entre escravos estabelecidos e novos correspondiam distinções simbólicas, com os mais estabelecidos reivindicando maior reconhecimento e respeito entre escravos e negros livres do que os recém chegados - e o insulto proferido pelo administrador implica que os novos eram estigmatizados. ${ }^{5}$ Ao comparar Cosme a um escravo novo, João de Godoy lembrava-lhe de que ainda era escravo; ao reagir, Cosme e seus companheiros se recusaram a serem tratados como escravos, exigindo um mínimo de dignidade e respeito.

A literatura recente sobre as últimas décadas da escravidão no Oeste Paulista demonstra a rebeldia crescente dos escravos, 
Desrespeito e violência: fazendeiros de café e trabalhadores negros...

manifesta sobretudo em fugas e em agressões violentas contra senhores, administradores e feitores (cf. Azevedo, 1987; Costa, 1998, p. 357-386; Machado, 1987; Machado, 1994). Alguns cativos reivindicavam a liberdade abertamente; outros lutavam para amenizar o ritmo do trabalho ou para defender direitos costumeiros de morar em unidades familiares, de lavrar roças próprias e de vender uma parte de sua produção (cf. Alaniz, 1997; Slenes, 1999; Xavier, 1996). Como a maior parte dessas lutas envolvia questões materiais, os pesquisadores têm prestado menos atenção aos aspectos simbólicos da resistência dos escravos. Além de ganhar maior autonomia, recursos e apoio social, esperavam abrandar o estigma da escravidão e aproximar o trato que recebiam ao dos negros livres (Mattos, 1998). A luta simbólica contra a escravidão é mais pesquisada por historiadores do ambiente urbano que do rural, talvez porque as opções de vida mais ou menos autônoma e o anonimato eram bem maiores nas grandes cidades. Sidney Chalhoub (1990), por exemplo, relata várias estratégias simbólicas que os escravos da Corte usavam para ofuscar as fronteiras entre cativos e livres e se apresentar, na vida cotidiana, como livres ou quase livres. $^{6}$

Para Orlando Patterson (1982, p.77-101), a sujeição gera a degradação do escravo e seu tratamento, pela população livre, como uma pessoa sem honra e sem a possibilidade de conquistá-la. $\mathrm{Na}$ linguagem de Bourdieu (2003, p.344-348), o escravo está fora do jogo do capital simbólico, desqualificado da competição pelo reconhecimento e pela distinção, que dão sentido à vida e fornecem razões para viver. James C. Scott (1990) desenvolve um argumento semelhante quando diz que as feridas mais profundas da dominação geralmente se derivam não da privação material em si, mas da vergonha da submissão involuntária e da humilhação de ter de aceitar abusos sem responder (abertamente). Patterson afirma que esse aviltamento gera o anseio não somente pela liberdade mas pela dignidade e por um lugar socialmente reconhecido e respeitado, ${ }^{7}$

Anos 90, Porto Alegre, v. 12, n. 21/22, p.103-149, jan./dez. 2005 
Karl Monsma

ou seja, o escravo desenvolve o desejo candente pela cidadania, nos termos de Marshall (1964, p.84), "um status conferido a todos que são membros plenos de uma comunidade".

A ânsia dos negros, sobretudo dos libertos, por respeito, pertencimento e tratamento digno sem dúvida continuou depois de 1888 , e a abolição provavelmente suscitou, em muitos, a esperança de que esse desejo fosse realizado. Aos libertos, a abolição final também permitiu maior liberdade para responder a insultos e tratos aviltantes, porque afrouxou - sem eliminar completamente

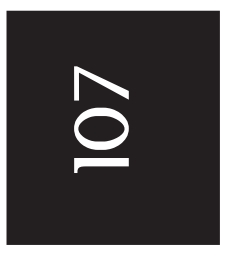
- os controles cotidianos anteriormente exercidos sobre os escravos. $^{8}$

Durante a colheita de 1894, sete anos depois do espancamento do administrador João de Godoy, o camarada mulato Domingos Antonio da Cunha reagiu de maneira semelhante aos comentários sobre seu trabalho. O dono da Fazenda Tanquinho, no atual município de Ibaté, Manoel Cardoso de Toledo França, chegou de uma viagem e foi inspecionar o cafezal. Insatisfeito com o serviço de Domingos e sua família, reclamou que eles tinham deixado muito café no chão, segundo um carreiro presente, ao que Domingos respondeu que seus filhos haviam apanhado nessa parte. ${ }^{9} \mathrm{O}$ fazendeiro claramente não gostou da atitude de Domingos, dizendo ao delegado depois que "o camarada Domingos Antonio da Cunha, mulato, respondeo grosseiramente a elle interrogado". Ao que parece, Manoel Cardoso considerava a resposta particularmente atrevida porque veio de um mulato.

Pouco tempo depois, conversando com Antonio Pinto de Magalhães, português que deu sua profissão como "lavrador" mas aparentemente era administrador ou empreiteiro na fazenda, Cardoso observou, conforme o carreiro,

[...] que um colono o havia ensinado a lidar com café e éra bom empreiteiro. Ouvidas estas palavras, Domingos disse a Manoel Cardoso: então patrão nós aqui não prestamos? 
Desrespeito e violência: fazendeiros de café e trabalhadores negros...

Manoel Cardoso, disse-lhe que não fallava com elle e que não fosse estupido. Neste momento Domingos retirou-se para casa.

Cardoso referiu-se a um colono estrangeiro, ou pelo menos assim Domingos entendeu. Com o fim da escravidão, as distinções entre nascidos livres, libertos e escravos, e entre escravos estabelecidos e novos, caíam gradativamente em desuso, mas com a imigração em massa, as divisões raciais e nacionais assumiram relevância crescente. É bem possível que Cardoso não queria dizer nada a respeito de Domingos com seu comentário sobre o colono, mas a sensibilidade de Domingos quanto a essa comparação indica que ele, e provavelmente muitos outros negros, se sentiam comparados com os imigrantes, muitas vezes de maneira inferiorizante. O rótulo "estúpido" só confirmaria, para Domingos, a opinião do patrão.

Algum tempo depois, quando o fazendeiro estava jantando com Magalhães e outros, Domingos apareceu na janela da casa armado com garrucha e pediu para ajustar suas contas. À resposta negativa de Manoel Cardoso, deu um tiro neste. O relato de um carpinteiro presente no jantar traz detalhes importantes dessa interação:

[...] estando elle depoente jantando com o offendido Manoel Cardoso de Toledo e outras pessoas, vio quando ahi chegou na janella pelo lado de fóra o mulato Domingos Antonio da Cunha e disse á Cardoso, que queria saber de que jeito havião de ajustar as suas contas, ao que Manoel Cardoso respondeo que fosse terminar o serviço que receberia e depois ajustavão contas, Domingos disse-lhe então que não ia acabar o serviço e que Cardoso lhe tratasse melhor visto que era tão cidadão como elle, disendo-lhe ainda Cardoso que agora é que elle Domingos estava sendo cidadão e Domingos puchando d'uma garrucha desfechou um tiro contra Cardoso que ficou offendido no braço direito. ${ }^{11}$ 
Karl Monsma

Com a abolição, os ex-escravos e outros negros esperavam ser tratados com o mesmo respeito que os brancos. Com seu discurso de cidadania, a República trouxe novos recursos retóricos, potencialmente vantajosos na luta simbólica dos negros. O conceito de cidadania também salientava a injustiça de favorecer estrangeiros sobre brasileiros negros. Mas este é o único caso encontrado até agora nos autos penais de São Carlos, em que um negro usa o discurso da cidadania explicitamente. Embora a preocupação de negros com dignidade e igualdade no trato transpareça nos

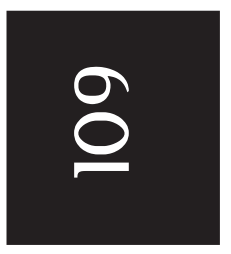
inquéritos e processos, a grande maioria formulava suas reivindicações em termos de respeito e não de cidadania, não somente por causa do analfabetismo e da ausência de uma elite negra, mas também porque o reconhecimento de sua humanidade era requisito básico para todas as outras formas de cidadania. ${ }^{12}$

\section{Os primeiros anos após a abolição em São Carlos}

A primeira colheita após a abolição não foi fácil para os fazendeiros. Podemos acompanhar aspectos da transição nas cartas do Conde do Pinhal, um dos maiores fazendeiros de São Carlos, para sua mulher. Em 1886, ele ainda exibia confiança na viabilidade do sistema, propondo à Assembléia Legislativa, onde era deputado, a revogação do imposto sobre a introdução de escravos novos na província. Em fevereiro de 1888, porém, evidenciava certa ansiedade, aparentemente por causa do número de escravos que já haviam fugido, escrevendo da Fazenda Pinhal: "Tudo se acha ainda em sossego em relação aos escravos porém a vista do sítio em que estou me parece que não poderei deixar de fazer alguma coisa mais em favor deles". ${ }^{13}$ Pouco depois do treze de maio, muitos libertos deixaram a Fazenda Pinhal e se assentaram próximo à entrada da cidade de São Carlos, fundando a Vila Isabel, até hoje um dos principais bairros de negros da cidade (Truzzi, 2000, p.52). 
Desrespeito e violência: fazendeiros de café e trabalhadores negros...

Em outubro, ao final da colheita de café, o conde contabilizou os danos devido à falta de mão de obra: "O nosso prejuízo este ano é horroroso. Creio que teremos acima de 20 mil arrobas do café que não poderemos levantar do campo além do deterioramento na qualidade de outro tanto." A situação também prejudicava a plantação de gêneros para o próximo ano. No início de novembro, escreveu "se não pudermos neste mês aprontar alguma roça ficaremos sem milho para comer para o ano em todas as fazendas". ${ }^{14}$ Mas nem todos os libertos deixaram a fazenda, e outros provavelmente voltaram depois de algum tempo fora. Em outubro de 1890, 22 libertos ou prováveis libertos (porque eram identificados somente pelo nome próprio) receberam salários na Fazenda Pinhal. ${ }^{15}$ $\mathrm{Na}$ Fazenda Palmital, propriedade de um genro do conde, mais de dois terços dos ex-escravos permaneciam em 1889 (Truzzi, 2000, p.51-52).

Existe certo mito a respeito dos municípios produtores de café do Oeste Paulista, segundo o qual a grande maioria dos negros abandonou as fazendas após a abolição. Devido a alguma combinação da discriminação racial e da auto-exclusão dos negros, nesta visão, imigrantes europeus monopolizaram os contratos familiares de colonato, com sua mistura de remuneração fixa pelo trato de certo número de cafeeiros, pagamentos variáveis dependendo da quantidade de frutos colhidos e direitos de plantar gêneros. Após o treze de maio, nessa versão tradicional, os negros só trabalhavam nas fazendas como camaradas, trabalhadores individuais assalariados, que cumpriam tarefas complementares como carretagem e manutenção de estradas, além de ajudar na colheita. No entanto, dados de um censo do município de São Carlos, realizado em 1907, mostram que "colono" era a ocupação mais comum entre homens negros arrolados como chefes de família, incluindo 43,5\% dos chefes pretos e 31,3\% dos mulatos (Monsma, 2006). Parece que, sejam quais fossem seus preconceitos, os fazendeiros não podiam excluir os negros do colonato porque, devido à 
expansão constante dos cafezais no boom da primeira metade da década do 1890 e à evasão dos colonos europeus durante a crise subseqüente, quase sempre precisavam de mão-de-obra. Do lado dos negros, alguns realmente migraram para as cidades, mas outros ficaram nas áreas rurais ou nas mesmas fazendas onde haviam sido escravos ou em outras. Embora rejeitassem o trabalho coletivo e rigorosamente supervisionado do eito, como Maria Helena Machado (2004, p.21-22) enfatiza, o trabalho familiar do colonato lhes era aceitável. ${ }^{16}$ Eles já conheciam o trato do café e, ficando na mesma fazenda ou em outra próxima, não precisavam se afastar dos parentes e amigos que também ficavam.

O ritmo da imigração aumentou notavelmente após a abolição, permitindo a rápida expansão da produção cafeeira nos anos subseqüentes. Entre 1889 e 1901, as cartas do conde não mais incluem reclamações de falta de trabalhadores para a lavoura, embora constem várias queixas sobre o ritmo de trabalho e as liberdades das empregadas domésticas, muito provavelmente libertas. Boa parte do problema, para os senhores, era a noção, nutrida por pelo menos uma parte dos libertos, de que eles agora deviam controlar seu próprio tempo (cf. Machado, 1994, p.43; Mattos, 1998, p.253-270).

A Raimunda, a Roberta e a Laura estão nas suas casas tranqüilamente sem me aparecerem. Não mandei e nem as mando chamar e desta vez se alguma delas aparecer amanhã é provavel que eu as dispense do serviço. Quero que vejam que posso passar com a Maria Preta e dispensar a elas.

Outra empregada estava furtando vinho e outras bebidas alcoólicas e se embebedando no serviço. ${ }^{17}$

Os trabalhadores especializados, outra categoria em que os negros se concentravam, geravam preocupações semelhantes, com o agravante de exigirem salários que o conde achava desmedidos. 
Desrespeito e violência: fazendeiros de café e trabalhadores negros...

Achei a casa em paz, porém os serviços do carpinteiro em completo atraso e todos eles fora de casa; vou amanhã atrás deles. O resto dos trabalhadores da turma que estarão em serviço hoje despediram-se. Há na vizinhança quem pague $40 \$ 000$ por mês.

É impossível saber quantos desses trabalhadores eram libertos, mas a falta temporária de certos tipos de trabalhadores e as atitudes dos libertos provavelmente minavam a disciplina e aumentavam as exigências dos nascidos livres e dos brasileiros brancos também. A frustração e a postura de um velho escravocrata transparecem na reação à demissão de outro trabalhador: "O Domingos Correa Lacio foi embora porque foi já aliciado 2 ou 3 vezes - fiz-lhe um grande obséquio em não lhe dar uma sova e assim dar-lhe um pouco mais de vergonha". ${ }^{18}$ Dez anos depois da abolição final, os hábitos de trabalho irregulares de alguns negros ainda irritavam o conde: "A sua lavadeira Theodolinda não pára aqui e agora há mais de 8 dias que anda por São Carlos, os filhos pequenos no Palmital, o Carlos sem trabalhar há 5 ou 6 dias e assim sendo eu tive de fazê-los desocupar o lugar". ${ }^{19}$

O comportamento de alguns negros parecia confirmar os medos dos brancos que, na véspera da abolição, os perceberam cada vez mais como depravados e traiçoeiros (Schwarcz, 1987). Em São Carlos, menos de dois meses depois do treze de maio, o liberto João foi acusado de estuprar, espancar e roubar uma mulher respeitável, que encontrara sozinha em uma chácara, deixando-a quase morta. Preso mais tarde, aparentemente no mesmo dia, foi entregue ao delegado. Porém, conforme o relatório anual do chefe de Polícia,

A população da cidade conspirou-se contra o réo, e na noite de 3 [de julho], ás dez e meia horas, mais ou menos, um grupo de cerca de quatro centos pessoas arrebatou o preso das grades da cadêa e assassinou-o, sendo o seu cadaver 
Karl Monsma

dependurado em uma arvore, no Largo da Matriz.

Consummado o crime, retirou-se o grupo, sem haver desordem e continuando a cidade calma, como é o seu estado normal. ${ }^{20}$

Causa admiração a afirmação de que não houve desordem logo depois da descrição de um linchamento. O chefe provavelmente copiou ou parafraseou um relatório sobre o evento enviado pelo delegado de São Carlos, que quis enfatizar que a violência foi direcionada somente contra o liberto. Ou seja, o delegado, e depois dele o chefe, deram a entender que João merecera o linchamento, pois a monstruosidade de seu crime havia excitado tamanha indignação na população de uma cidade pacata. Uma interpretação alternativa focaliza a população branca. O medo de rebeliões e da violência de escravos perpassara os últimos anos da escravidão; alguns brancos (e talvez, alguns mulatos) sem dúvida achavam que a emancipação soltou uma multidão de feras, e aguardavam com nervosismo uma onda de violência e barbárie. Um evento como o estupro na chácara, que parecia confirmar seus medos, estimulou-os à ação enérgica para expressar repugnância, vingar a honra coletiva dos brancos e amedrontar os outros libertos. É significativo que o linchamento não foi espontâneo, mas planejado, acontecendo dois dias depois da prisão do liberto. Apesar de "rigoroso inquérito", conforme o chefe, foi impossível descobrir os autores do linchamento. Claramente a população protegia o grupo que planejara o evento, mas o resultado do inquérito também sugere que as autoridades locais foram complacentes.

Outro evento que chocou a população local, dez anos depois, foi o suicídio do fazendeiro Dr. Arthur da Costa Pires, depois de saber que sua filha de 16 anos fora deflorada e engravidada por um "antigo criado" da casa (provavelmente ex-escravo doméstico). Philomeno da Conceição, preto de aproximadamente 50 anos, natural de Maranhão, aparentemente havia servido a família por

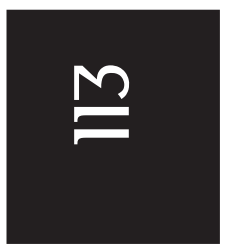


Desrespeito e violência: fazendeiros de café e trabalhadores negros...

muitos anos. Várias testemunhas enfatizaram depois que o fazendeiro havia depositado total confiança nele. Fica aparente no inquérito que ele e a menor tiveram relações sexuais várias vezes no decorrer de quatro ou cinco meses, até a moça revelar isso a sua avó. $^{21}$

Para o pesquisador de hoje, um dos aspectos mais interessantes deste caso é o fato de que o defloramento levou o fazendeiro a se suicidar, não a matar o liberto, o que teria sido a reação mais comum de fazendeiros em situações parecidas. Para uma família de meios, também era possível compensar o defloramento e a gravidez indesejada. A moça podia ser mantida na casa até o parto e o recém-nascido entregue a outros para criar. Depois, a família podia pagar um bom dote a um homem da classe média que aceitasse se casar com a filha, resultando em uma união, senão ideal, pelo menos aceitável. Portanto, o defloramento e a gravidez, sem a concorrência de outros fatores, não explicam o suicídio. A desonra da família tampouco serve como motivo, porque a situação só ficou conhecida ao público em decorrência do suicídio. Sem este ato, teria sido muito mais fácil encobrir o defloramento. Desconfio que o Dr. Pires entrou em profunda depressão por causa da traição de um empregado em que ele confiara tanto, combinada com a participação ativa da filha no próprio defloramento - outra forma de traição. Isso teria criado a sensação de que a realidade estava completamente distinta do que ele havia imaginado, que até os mais íntimos conspiravam contra ele, que não podia confiar em ninguém. Para o público local, o defloramento da moça e o suicídio do fazendeiro simplesmente confirmaram a natureza traiçoeira dos negros.

Tais acontecimentos e outros parecidos de outros lugares ganhavam publicidade na imprensa local, que cedo descobriu que publicar histórias chocantes e bizarras era bom para vender jornais. Os que queriam acreditar que os negros eram naturalmente pervertidos podiam achar evidências para apoiar suas crenças, mas 
Karl Monsma

como esses eventos eram relativamente raros e os negros logo ficaram isolados entre a grande massa de imigrantes, o medo branco diminuiu com o passar do tempo. Contrariamente ao que alguns podiam ter esperado em 1888, não houve mais linchamentos em São Carlos depois da morte de João. O deflorador Philomeno foi julgado e condenado a cinco anos, cinco meses e dez dias de prisão, sem interferência extralegal da população local. Também parece que a conivência das autoridades locais com a violência contra os negros ficou mais limitada, restrita principalmente aos casos

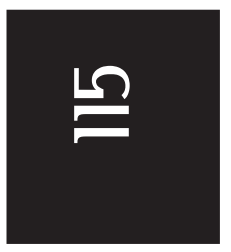
em que os acusados eram fazendeiros ou outros membros da elite. Deixar os brancos pobres imporem suas vontades pela força seria encorajar comportamentos perigosos, sobretudo com a afluência massiva de estrangeiros pobres. Cada vez mais, as elites locais viam a violência de imigrantes, sobretudo de italianos, como uma ameaça maior que a dos negros.

Os estereótipos raciais negativos que predominavam após a abolição, evidentes tanto nos autos penais como nos jornais, eram do negro vadio, ladrão ou alcoólatra, figuras desprezíveis mas não temíveis. De fato, muitos negros foram acusados de furtos, sobretudo furtos de cavalos, em São Carlos nas primeiras décadas após a abolição. Parece que, para alguns libertos, a prática de pequenos furtos, anteriormente comum como forma de resistência à escravidão e maneira de amenizar a vida dos cativos, não cessou com o treze de maio. Muitos outros foram acusados de vadiagem ou embriaguez.

Também havia o estereótipo do "bom negro", humilde e trabalhador, que aceitava a tutela do ex-senhor ou de outro integrante da elite local. Como é evidente no caso do conde do Pinhal, os fazendeiros tentavam ficar com esses trabalhadores negros e se livrar dos que consideravam ruins. Ao mesmo tempo, ficavam atentos para qualquer sinal de desacato, e facilmente usavam a violência física contra negros desobedientes. O perigo de rebeliões de escravos ficara no passado, mas os fazendeiros, traumatizados, ao 
Desrespeito e violência: fazendeiros de café e trabalhadores negros...

que parece, pela rebeldia e as fugas dos anos 80 , não esqueceram. Sua prontidão para agredir os negros sugere certa inconformidade com o fim da escravidão e desejo por vingança. Os hábitos de trabalho, um tanto irregulares, de alguns negros só podiam intensificar a irritação dos fazendeiros e seus administradores.

\section{Lutas simbólicas após a abolição}

Na sexta-feira santa de 1894, Antonio Augusto de Oliveira, 19 anos, professor na fazenda de João Evangelista Terra, mas que aparentemente tinha um papel administrativo também, foi esfaqueado pelo colono preto José Francisco, viúvo de 40 anos, quando o espancava com bordoadas. José Francisco declarou ao delegado depois que "attribui a intenção de Oliveira em querer lhe dar pancada ao facto delle respondente não ter ido a roça na segunda feira, dezenove do corrente, por que nesse dia tendo matado um porco ficou em casa lidando com o mesmo". ${ }^{22}$ Antonio Augusto havia chamado José Francisco para irem juntos à casa do patrão pedir sua mediação no conflito, mas surpreendeu o negro no caminho com as pancadas. Segundo uma testemunha,

[...] logo pela manha estava elle depoente no chiqueiro da fazendo occupado em tratar dos porcos quando vio Antonio de Oliveira e Jose [...] que dirigião-se para a casa da fazenda; que em caminho Antonio de Oliveira voltando-se para Jose deo neste uma bordoada que o lançou por terra, Jose tentando levantar-se, tomou segunda bordoada, tentando ainda terceira ves tomar terceira bordoada, mas conseguindo levantar-se cravou uma facada em Antonio de Oliveira, facada esta que produsio the a morte uma hora mais ou menos depois. ${ }^{23}$

Aqui aparece claramente a tendência do negro - provavelmente ex-escravo, porque sem sobrenome no processo - reivindi-

Anos 90, Porto Alegre, v. 12, n. 21/22, p.103-149, jan./dez. 2005 
car o controle do seu tempo e trabalhar para outros quando lhe convinha. $\mathrm{O}$ mestre se irritou com essa atitude o suficiente para dar pancadas em José Francisco, mas parece que não odiava os negros em geral. Algumas semanas antes, havia se arriscado para tentar resgatar um negro da investida de quatro italianos, dando uma pancada na cabeça do italiano que o esfaqueava. ${ }^{24} \mathrm{~A}$ raiva de Antonio Augusto contra José Francisco, como na maioria das brigas entre negros e fazendeiros ou administradores, era situacional. Os brancos se enfureciam com negros que desobedeciam e traba-

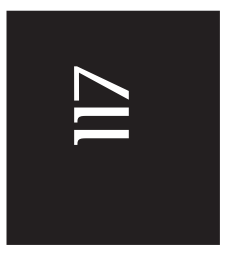
lhavam quando queriam, e alguns negros se recusavam a aceitar castigos físicos.

Em 1907, um administrador atirou no seu ajudante "moreno" em um baile do dia de São João porque este o desacatou. O administrador, Ananias Torres Pimenta, posteriormente declarou ao delegado que durante o dia, o ajudante Carlos Leite Portella "portou-se inconvenientemente á ponto de por questão de ordem de serviço desrespeitou o declarante chegando mesmo a insultalo, pelo que resolveu pedir sua demissão e nesse sentido escreveu ao patrão". ${ }^{25}$ Nessa noite, de lado de fora da casa onde acontecia o baile, segundo um trabalhador espanhol,

[...] ouvio Ananias dizer á Portella "- eu te atiro, eu te atiro"; que Portella respondeu duas vezes " - deixe de caçoada seu Ananias!" -, eis senão, quando, Ananias, saccando de uma garrucha desfechou um tiro em Carlos Leite Portella, que sendo attingido ficou ferido.

Outro espanhol ouviu o administrador dizer "eu queimo" e Carlos responder "deixe de brincadeira" antes do tiro. ${ }^{26}$ Aparentemente Ananias já havia antes ameaçado atirar no ajudante, porque este disse ao delegado que "até o momento de ser ferido, sempre pensou que Ananias fizera a promessa de atirar-lhe por brincadeira". Para o administrador, evidentemente, o desrespeito do ajudante durante o dia era assunto sério, e parece que ele percebeu a 
Desrespeito e violência: fazendeiros de café e trabalhadores negros...

resposta "deixe de caçoada [ou de brincadeira]" como mais insolência. É duvidoso se o administrador teria respondido a um ajudante branco da mesma maneira. Podia ter demitido um branco levado, mas provavelmente não teria atirado nele. Os fazendeiros e administradores ficavam sumamente irritados com negros que desacatavam, que respondiam com impertinência, que não agiam humildemente como "bons pretos", enfim, como os que "não sabiam seu lugar".

Contudo, a maioria da violência entre negros e autoridades das fazendas não se relacionava diretamente com o trabalho, mas com a intromissão de fazendeiros e administradores na vida privada dos negros e com a resistência destes a tal interferência, muitas vezes vista como desacato. Em novembro de 1891, o fazendeiro Joaquim Garcia Ferreira mandou um empregado levar uma "preta velha", que se encontrava embriagada e caída no chão, de volta para a casa de sua filha. Quando o empregado levava a mulher para dentro da casa, chegou o genro dela, Inocêncio Balbino Ferreira, e exclamou, segundo sua amásia, Sebastiana Carneira, "filho da puta o que está fazendo dentro da minha caza?" 27 e o puxou para fora. Depois entrou na casa de novo e saiu armado de uma faca e um cano de espingarda. Ouvindo o barulho, o fazendeiro veio e, na versão do empregado, mandou Inocêncio parar. Quando este não obedeceu, deu-lhe voz de prisão. ${ }^{28}$ Sebastiana, por outro lado, disse depois que Joaquim Ferreira "ralhou com Inocencio por ter este se alterado". Seguiu-se a esta interação uma luta entre o fazendeiro, seu filho e o empregado, por um lado, e Inocêncio e seu irmão Misael, por outro, saindo feridos Inocêncio, seu irmão e o filho do fazendeiro.

Inocêncio e Misael nasceram em Minas Gerais e haviam chegado a São Carlos em 1879, muito provavelmente como escravos. Inocêncio claramente reagiu ao que percebeu como violação do lar e da privacidade da família, abusos típicos de escravocratas. $\mathrm{Na}$ versão de Sebastiana, o ralhar paternalista de Joaquim, como 
Karl Monsma

se Inocêncio fosse uma criança, também irritou este. Para o fazendeiro, a questão central era a desobediência de Inocêncio e sua atitude desafiadora. Um carpinteiro que não presenciou o início da briga, mas ajudou a prender os negros, disse depois "que sabe que a razão da prizão foi terem estes dezobedecido a ordem de prizão dada por Joaquim Garcia e terem se levantado contra o dito Garcia armados de facas e cacetes". ${ }^{29}$

Alguns fazendeiros desrespeitavam até os direitos de pais e mães negros sobre seus filhos. No início de 1892, Ozoria Maria da Conceição, filha da preta Luzia do Espirito Santo, com 13 ou 14 anos, foi trabalhar na casa do fazendeiro Francisco da Rocha Camargo Arruda. Este disse depois que Luzia havia "dado" sua filha: "Luzia tinha dado sua filha de nome Ozoria a mulher delle respondente para prestar-lhe serviços domesticos". ${ }^{30}$ Pouco mais de um ano depois, Luzia, avisando por "alguns camaradas" que "a menina podia lá se perder", resolveu trazer a filha, agora com 15 anos e noiva, de volta para sua casa, mas o fazendeiro se recusou a entregar a moça. ${ }^{31} \mathrm{Com}$ isso, Luiza resolveu tirar a filha furtivamente à noite. Ela foi à fazenda com o noivo da filha e dois outros, aproximando-se sozinha à casa e chamando Ozoria pelo nome, mas esta contou para a patroa que ouviu uma voz parecida com a da sua mãe a chamando, e o fazendeiro, seu filho e o administrador espanhol afugentaram o grupo com tiros. Um dos companheiros de Luzia, que havia atirado de volta, foi baleado no rosto pelo administrador e perdeu um olho.

Em julho do mesmo ano, o trabalhador preto Maximiano, com uma faca na mão, discutia com Eugenio, ao que parece também negro, na porta de uma casa na Fazenda de São Domingos da Gramma, de Teófilo de Toledo França. Outros mandaram um menino chamar o fazendeiro. Este logo chegou junto com o administrador e o filho deste. Os três tiraram Maximiano da casa, mas este, segundo o administrador, 
Desrespeito e violência: fazendeiros de café e trabalhadores negros...

[...] no terreiro ficou ainda mais valente dizendo que naquelle dia estava disposto matar uns dois ou trez; mais apesar de tudo elle depoente com Theophilo conseguirão fazer retirar a Maximiano para fora do terreiro em que se achava, na mesma hora porem o mesmo Maximiano voltou dizendo que não obdecia a ninguem nem a elle seu patrão nem a Theophilo pegando-lhe no braço disse-lhe que lhe obdecesse e ali Maximiano o encarou tomando uma posição de quem estava disposto ao que desse e viesse e Theophilo deu-lhe uma pancada que o derrubou por terra. ${ }^{32}$

Teófilo golpeara Maximiano na cabeça com um porrete, e Eugenio aproveitou para dar-lhe uma pancada também. Maximiano morreu uma hora depois. Já esquentado por álcool e pela discussão, Maximiano se enfureceu com a interferência do patrão na sua briga. Quase todas as testemunhas, várias das quais só souberam da briga dos outros, enfatizam a desobediência e a atitude desafiadora de Maximiano como os motivos da pancada do fazendeiro.

Em 1894, o fazendeiro João Augusto do Amaral e Silva matou Irineo, trabalhador preto, em circunstâncias parecidas. Era noite e Irineo discutia com outro trabalhador na porta da casa do fazendeiro. Aparentemente a briga acordou o fazendeiro, que saiu e empurrou Irineo com um pedaço de pau, ordenando que fosse embora e que parasse de fazer barulho. Mas Irineo continuava discutindo com o outro e João Augusto deu-lhe uma pancada, levando-o à morte alguns dias depois (Medeiros, 2004, p.71).

Em abril 1900, João de Sampaio Pinto, viúvo pardo, também conhecido como João Maquinista, que vivia como agregado junto com seus dois filhos na casa de um fazendeiro, trabalhando na construção de um moinho enquanto "esperava a colheita de café para se empregar como machinista", atacou o dono da casa com navalha por este ter interferido nas suas relações com um dos filhos. ${ }^{33}$ João disse depois ao delegado que repreendia seu filho verbalmente quando foi agredido sem motivo pelo fazendeiro, José 
Bueno do Prado, vulgo José Gordo. Entretanto, o fazendeiro, que agonizou por algum tempo antes de morrer, disse que tentava proteger o filho do pai e expulsou este da casa por ter agredido o filho, o que motivou as navalhadas um tempo depois. O filho de João Maquinista negou os maus tratos do pai e enfatizou a interferência do fazendeiro na vida familiar:

[...] estando elle depoente a conversar com seu páe o qual fallava alto por que elle depoente é meio surdo chegou-se ao quarto onde conversavam José Bueno do Prado e perguntou-lhes o que era aquillo ao que João Pinto respondeu: 'não é nada, é negocio de familia'; que então Bueno pegou João Pinto pelas orelhas e bateu com a cabeça d'este na porta e que botou-o para fora do quarto dando-lhe bofetadas; que então o réo voltando ao quarto onde dormia pegou de uma navalha e sendo novamente agredido, produsio com ella ferimentos em Bueno. ${ }^{34}$

Um negociante espanhol, concunhado do fazendeiro, confirmou que este agrediu o pardo, mas insinuou que José Gordo agiu dentro de seus direitos como chefe da casa:

[...] estando o depoente em casa do offendido Bueno do Prado em um quarto contiguo á casa armou se uma contenda entre o denunciado e seu filho Sebastião; que Bueno levantou-se da salla de jantar a fim de apaziguar o barulho o que conseguio ralhando com o denunciado aquem tambem applicou umas bofetadas; que, apaziguado o barulho sahio o depoente para o seu serviço ouvio gritar de socorro e que voltando para a casa vio José Bueno cahido por terra, ferido e com as tripas de fóra. ${ }^{35}$

Em outra ocasião, um fazendeiro sente-se justificado em interferir na vida familiar de um negro, e este tenta defender as prerrogativas de um pai de família daquela época. A tendência de os 
Desrespeito e violência: fazendeiros de café e trabalhadores negros...

fazendeiros reinarem soberanos nas suas propriedades e de perceber os negros como homens sem honra, dependentes do senhor, justificando poderes ilimitados sobre eles, não morreu com a escravidão. Se os fazendeiros e seus administradores mostrassem prepotência no trato com todos os trabalhadores, evidenciavamna ainda mais nas relações com os negros, e continuavam exigindo a deferência servil de libertos e de outros negros por muitos anos após a abolição. Sentiam-se à vontade para "ralhar" com os negros - palavra que aparece repetidas vezes nos autos decorrentes de violência entre estes e fazendeiros ou administradores - e parece que a desobediência dos negros os irritava profundamente. De sua parte, os negros reivindicavam respeito à sua vida privada, e muitos deles lutavam para defender seus direitos como pais de família.

Quase duas décadas após a abolição final, os desmandos de fazendeiros e administradores para com os negros continuavam. Em uma noite no início de novembro de 1907, Sebastião Leite, colono preto da Fazenda da Horta, brigava com sua amásia, segundo testemunhas, porque esta queria abandoná-lo e juntar-se com um caboclo, quando o administrador, Jeremias de Oliveira Barboza, chegou e o agrediu com um podão. $\mathrm{Na}$ versão do administrador,

[...] na qualidade de administrador, que era da fazenda Horta, teve necessidade de por trez vezes, na noite de $1^{\circ}$ de Novembro do anno passado, admoestar ao camarada ou colono da fazenda, Sebastião Leite, que estava praticando disturbios; que na terceira e ultima vez que o admoestou, foi já depois de haver tocado silencio na fazenda e nessa occasião Sebastião Leite desrespeitou-o, [ilegível] e investindo contra elle interrogado; que então elle interrogado, assim agredido, para se defender e tambem para manter a sua força moral, como administrador, deu em Sebastião diversas pancadas, com o cabo de um podão. ${ }^{36}$ 
Se, para Jeremias, a questão central era o desrespeito do preto e a necessidade de sustentar sua autoridade como administrador, para Sebastião era a invasão do seu lar e a violência injustificada do administrador:

[...] que hontem estava em sua casa sita na fazenda Horta deste municipio, em companhia de sua amasia Anna Maria de Jesus e de Benedicto de Tal as nove horas da noite mais ou menos entrou em sua casa o administrador da referida fazenda, Jeremias Barboza que sem proferir palavra alguma deu-lhe diversas pancadas com uma pequena facca ou melhor com um podão. ${ }^{38}$

Segundo a amásia, que negou ter aceito o convite do caboclo, Jeremias disse "seu cachorro você não me obedece" antes de agredir Sebastião.

Um mulato que estava junto com o casal e que interveio para proteger Sebastião, queria, ao que parece, se distinguir do preto, várias vezes chamando este "o preto Sebastião" no seu depoimento, que retrata a ação do administrador como razoável e enfatiza a desobediência de Sebastião:

Jeremias logo que chegou procurou acalmar o preto Sebastião; que a principio conseguiu o seu intento, mas que logo em seguida Anna fez novamente mensão de acompanhar Alexandre que se achava proximo indo-se embora da fazenda, pelo que Sebastião travou nova discução com Anna, que então Jeremias ordenando ao preto que se calace foi por este desobedecido, pelo que Jeremias aggrediu o preto Sebastião dando-lhe diversas pancadas com uma foice com que estava armado; que nesse momento o depoente interveio na questão; empurrando Jeremias pára fora da casa. ${ }^{39}$

Uma vizinha italiana, por outro lado, culpava o administrador, depondo que este disse a Sebastião "Não me abuse, negro, si 
Desrespeito e violência: fazendeiros de café e trabalhadores negros...

não te mato", e acrescendo que "ouviu dizer que Jeremias Barboza não é um bom administrador, tendo havido queixas contra elle em todas as fazendas em que tem estado". ${ }^{40} \mathrm{Na}$ época, "negro" era um insulto ("preto" era mais neutro), que servia para rebaixar os negros, lembrando-os do estigma da escravidão e de sua posição subalterna.

Um colono português enfatizou os insultos de ambos os lados: "sendo Jeremias insultado por Sebastião, chamou-o de cachorro e dizendo que ia matal-o deu-lhe diversas pancadas na cabeça com uma foicinha". ${ }^{41}$ Imigrantes também sofriam a prepotência e violência dos fazendeiros e administradores. Portanto não é de surpreender que agressões destes contra negros às vezes evocavam simpatia pelas vítimas, ou pelo menos sentimentos ambivalentes, em imigrantes.

Às vezes, parece que as autoridades das fazendas agrediam indivíduos negros só para se divertir ou para expressar o ódio generalizado contra todos os negros. Em 1897, o filho de uma fazendeira agrediu um empreiteiro de outra fazenda, aparentemente negro (nasceu em Pernambuco), a pancadas simplesmente por ele estar na fazenda da mãe. A vítima, segundo sua declaração ao delegado, foi cobrar uma dívida a um trabalhador e já havia falado com a fazendeira quando:

[...] sahio seu filho Francisco Terra e vendo elle declarante, perguntou-lhe ao que viera; elle disse que vinha receber dinheiro de Firmino, Francisco Terra disse que se retirasse e que esperar-se que elle lhe pagaria; acto continuo, voltou para fora e armado de cacete deu com este muitas bordoadas, não querendo attender a sua mãe que nesta occasião chegou e quis appartal-os. ${ }^{42}$

O delegado coronel Leopoldo Prado, também fazendeiro, arquivou os autos sem ouvir testemunhas, alegando que os 
ferimentos eram leves e que a vítima não havia "dado a queixa nos termos da lei".

Na vila de Santa Eudóxia em 1901, o fazendeiro Agostinho da Cunha Caldeira deu uma pancada na cabeça de Manoel Candido, mulato que havia sido camarada dele em outra fazenda, onde Agostinho fora ajudante do administrador, porque encontrou o mulato brigando com os donos italianos de uma venda. Depois da prisão de Manoel, este foi "barbaramente espancado" por Agostinho, segundo o chefe da estação ferroviária do local. ${ }^{43}$ Fica claro na declaração de Agostinho, ao delegado, que aquele nunca gostara de Manoel:

[...] em mil e oitocentos e noventa e três, elle declarante sendo ajudante de administrador na fazenda da Figueira Branca, [...] tinha como camarada um individuo de má tempera de nome Manoel Candido que lógo sahio despachado da fazenda por ter promovido divérsas desordens na referida fazenda.

Ao que parece, Agostinho já queria surrar Manoel, e a briga deste com os italianos serviu como pretexto.

Em 1913, Ezequiel Theodoro da Silva, ajudante branco do administrador da fazenda Palmeiras tentou prender um pardo que havia ameaçado a família de um português porque este recusara o pedido do pardo para casar com sua filha. Encontrando o pardo, José Ribeiro da Silva, vulgo José Bahiano, deu-lhe uma pancada na cabeça, justificando depois que o pardo havia lhe respondido "arrogantemente". ${ }^{44}$

Em todos esses casos, fazendeiros, administradores ou ajudantes de administradores reivindicavam a obediência incondicional de pretos ou mulatos, e recorriam rapidamente à violência quando negros não demonstravam deferência. Podemos nos perguntar se as autoridades das fazendas tratavam os negros de maneira diferenciada ou se manifestavam tal prepotência e tendência para a 
Desrespeito e violência: fazendeiros de café e trabalhadores negros...

violência nas relações com todos os trabalhadores. Ou seja, as atitudes de fazendeiros e administradores a respeito dos negros podem ser manifestações principalmente de relações de classe, não de racismo. $\mathrm{Na}$ realidade, as hierarquias de classe e raça estavam sobrepostas, e os fazendeiros não tinham a mesma preocupação do sociólogo de hoje em diferenciar os efeitos de classe e raça. Para os fazendeiros, certamente era natural que negros ocupassem posições subalternas; não imaginavam que a abolição significaria a igualdade racial porque acreditavam, como a maior parte da elite intelectual, na inferioridade congênita do negro, sobretudo no que dizia respeito às suas capacidades mentais. Entanto, muito do pensamento da época sobre classes sociais também incluía uma dimensão "racial", enfatizando a superioridade nata das elites (Malik, 1996, p.79-100). Tanto negros como trabalhadores eram vistos como naturalmente inferiores.

Mas existem algumas evidências que ajudam a avaliar o peso do racismo na violência de fazendeiros e administradores contra trabalhadores negros. O uso de insultos raciais em alguns casos sugere que fazendeiros e administradores distinguiam negros dos outros trabalhadores, e os desprezavam mais por serem negros. Também havia diferenças entre essas brigas e as entre autoridades das fazendas e trabalhadores imigrantes, sugerindo divergências importantes nas relações de fazendeiros e seus agentes com esses dois grupos de trabalhadores. As brigas entre imigrantes e as autoridades das fazendas geralmente se originavam de questões materiais, tais como tentativas, por parte de imigrantes, de se demitir, multas consideradas arbitrárias, atrasos nos salários, desentendimentos sobre dívidas às vendas, tentativas de organizar greves ou a recusa de trabalhar à noite e de cumprir tarefas desagradáveis (Monsma, 2005). Por outro lado, a maior parte da violência entre negros e fazendeiros ou seus agentes começava com questões mais simbólicas, envolvendo comportamentos de negros percebidos como desacatos pelas autoridades das fazendas e ações destes 
Karl Monsma

sentidas por negros como aviltantes. Os fazendeiros e administradores desrespeitavam a vida privada dos negros, tratavam-nos como crianças e exigiam a submissão, ao passo que os negros lutavam para defender sua privacidade e controlar seu próprio tempo, e alguns se recusavam a se humilhar.

Fazendeiros e administradores também recorriam à violência física mais rapidamente em resposta aos desacatos de negros do que de imigrantes. Quando um imigrante demonstrava desrespeito, a primeira resposta dos fazendeiros, administradores ou di-

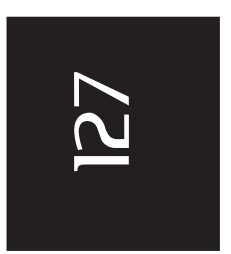
retores de colonos era multá-lo, descontando o valor do salário. Às vezes, multas impostas a imigrantes redundavam em violência física, mas somente depois da intensificação da briga via troca de insultos, e, muitas vezes, o imigrante era o primeiro a valer-se da violência. Em nenhum dos casos discutidos acima, o fazendeiro ou administrador impôs uma multa ao negro por desacato; em vez disso, foram diretamente para a violência física. Em parte, isso pode se derivar da noção escravista de que os castigos corporais eram necessários para sustentar a "autoridade moral" dos senhores entre os negros. Mas a violência de fazendeiros e administradores contra negros era quase sempre impulsiva, não calculada, evidenciando, muitas vezes, uma fúria descontrolada. Parece que a insolência de negros era particularmente irritante para os fazendeiros. Um dos principais legados do escravismo era a noção, internalizada no babitus dos fazendeiros, e de muitos outros brancos, de que os negros eram uma raça feita para servir, que eles deviam sempre manifestar deferência a seus superiores "naturais". A rebeldia dos últimos anos da escravidão só podia ter aumentado a sensibilidade dos fazendeiros e administradores a qualquer sinal de desacato.

A rapidez com que fazendeiros e administradores respondiam com violência aos negros insolentes também sugere que não lhes custava muito sacrificar negros inconvenientes. Se, antes da abolição, alguns fazendeiros matavam negros rebeldes, mesmo 
Desrespeito e violência: fazendeiros de café e trabalhadores negros...

quando isso significava a destruição de parte de seu capital, após o treze de maio eles não perdiam nada, economicamente, com a morte de trabalhadores negros. $\mathrm{Na}$ justiça, também gozavam de alto grau de impunidade. Dos casos discutidos acima, de agressões de fazendeiros ou administradores contra negros, somente o administrador que atirou no seu ajudante foi condenado na Justiça. Já os negros que agrediam fazendeiros ou seus agentes arriscavam outro tratamento. Dos negros acusados nos casos acima, alguns foram absolvidos, outros não. João Maquinista recebeu uma sentença de dez anos e meio de prisão pelas navalhadas que deu no fazendeiro José Bueno do Prado. Domingos Antonio da Cunha, o que reivindicava a cidadania, foi condenado a dez anos de prisão celular (convertido em onze anos e oito meses de prisão comum) por ter atirado no fazendeiro, causando-lhe ferimentos leves. Em 1905, quando a sentença estava quase terminada, foi declarado demente e internado no Hospício de Alienados em São Paulo, onde morreu de tuberculose em 1915.

Até ocupar posição de autoridade nas fazendas não poupava os negros do racismo, que surgia abertamente sobretudo nos momentos de conflito. Na sexta-feira antes do carnaval de 1895, Alberto José de Castro, negro, administrador da fazenda Santa Emília, do coronel Gentil José de Castro, e Emydio Garcia Vieira, branco, administrador da fazenda Gatervéa, do mesmo dono, supervisionavam colonos dessas fazendas no conserto da estrada que ligava as duas. Chegando à divisa entre as fazendas, Alberto dispensou seus colonos, mas Emydio o mandou continuar adiante até chegar na sede da fazenda Gatervéa. Alberto respondeu, segundo sua declaração ao delegado, "que isso era impossível por que não podia mais fazer esse serviço visto que as duas colônias não tinhão feito o caminho da fronteira pertencente a fasenda onde o depoente administra, em diante." 45 Com isso, Emydio ameaçou multar Alberto e os colonos da fazenda Santa Emília, e Alberto, na versão de uma testemunha italiana, "perguntou a Garcia o que 
queria com elle e que não podia multar" ${ }^{46}$ Essa desautorização enraiveceu Emydio, que gritou, segundo um colono brasileiro,

[...] vá puta que o pario, negro do diabo, filho da puta, e se approximou de Alberto em quem deo uns tapas sendo repelhido por Alberto com guarda-chuva e estava nisto quando Garcia puchou por um facão e deo-lhe um golpe que pegou no dedo de Alberto e continuara nessa lucta quando Alberto puchou pelo revolver e deo-lhe alguns tiros sahindo depois tendo deixado já no chão o mesmo Garcia que morreo alguns minutos depois. ${ }^{47}$

Vários dos colonos ficaram impressionados não somente com a morte mas também com a violência da linguagem de Emydio, repetindo os insultos (com algumas permutações). Quando questionadas pelo juiz, as testemunhas disseram que Alberto e Emydio eram amigos. Um colono italiano disse que "estes davam-se, andavam juntos e freqüentaram a casa um do outro"; outro disse que "sempre os viu andar juntos e até comer juntos". 48

Apesar de os dois administradores serem iguais, Emydio supunha que podia mandar em Alberto porque era negro. Quando Alberto resistiu a essa hierarquização, Emydio ficou furioso e tentou lembrá-lo de seu lugar, e do estigma da escravidão, com o insulto "negro". A semelhança entre o nome de Alberto José de Castro e o do fazendeiro Gentil José de Castro sugere algum grau de parentesco - é até possível que Alberto fosse filho natural do fazendeiro -, o que pode explicar como Alberto, negro e com somente 23 anos, chegou a ser nomeado administrador. Se esta linha de raciocínio estiver correta - e não existem indícios a respeito nos autos - é provável que Alberto não fosse preto, mas mulato, e o insulto de Emydio lhe lembrava que, seja qual for sua posição social, ainda era parcialmente preto. 
Desrespeito e violência: fazendeiros de café e trabalhadores negros...

\section{Relações de fazendeiros e administradores imigrantes com negros}

Quando imigrantes compravam fazendas ou ganhavam posições de autoridade nelas, rapidamente adotavam atitudes a respeito de trabalhadores negros semelhantes às dos fazendeiros brasileiros. Alguns desses imigrantes, sobretudo portugueses, chegaram antes de 1888 e haviam sido escravocratas, mas a grande maioria não tinha nenhuma experiência com a escravidão. Demorou mais para os outros grupos principais de imigrantes, os italianos e espanhóis, adquirirem fazendas, embora integrantes desses grupos apareçam relativamente cedo entre os administradores de fazendas, diretores de colonos e empreiteiros. Os italianos constituíam de longe o maior grupo imigrante em São Carlos, chegando a constituir, junto com seus filhos, aproximadamente a metade da população enumerada no censo municipal de $1907 .{ }^{49} \mathrm{O}$ Estatística agrícola e zootécnica no ano agrícola de 1904-1905 arrolou quarenta proprietários italianos no município de São Carlos, treze portugueses e cinco espanhóis, além de 251 proprietários brasileiros e quatro de outras nacionalidades (Truzzi, 2004, p.71).

A facilidade com que imigrantes adotavam a mentalidade escravocrata mostra que a escravidão em si não era necessária para que as pessoas internalizassem essas atitudes. Bastava os brancos brasileiros sistematicamente tratarem os negros como congenitamente inferiores e feitos para servir, e os imigrantes recémchegados rapidamente aprendiam a tratá-los da mesma maneira.

Um dos imigrantes mais violentos era o português Antonio Pinto de Magalhães, vulgo Antonio Bravo. Era o administrador (ou empreiteiro) do fazendeiro Manoel Cardoso de Toledo França em 1894, quando este, em um incidente discutido acima, foi alvejado pelo mulato Domingos Antonio da Cunha, que se sentia comparado injustamente com os imigrantes. Magalhães havia chegado a São Carlos em 1877, com 19 anos de idade, e possivelmente era 
ex-escravocrata. Em 1897 morava na aldeia de São João da Lagoa (posteriormente Ibaté) e ainda se dizia "lavrador", embora não tivesse pago o imposto sobre o café desse ano (Truzzi, 2004, p.3637 ), o que sugere que ele continuava como administrador ou tinha um sítio.

Em junho desse ano ele deu uma pancada na cabeça de seu camarada Roberto Rosa, preto de 40 anos, e o surrou de chicote porque este não havia cortado capim para um cavalo. Ele encontrou Roberto numa venda conversando e chamou-o de volta para

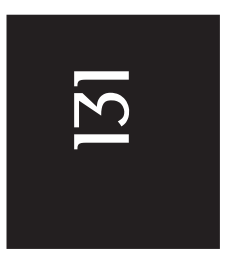
casa. Roberto acedeu à chamada e, segundo sua declaração ao subdelegado,

[...] depois que chegou e entrou, Magalhães com as mãos atráz, e assim que delle se approximou recebeu uma pancada que o prostou por terra e logo em seguida pelo mesmo Magalhães foi lhe dada uma sova de reio, que só sessou quando appareceu ao local Agostinho José. ${ }^{50}$

Esse "Agostinho José" era Agostinho Luiz Henklern, construtor brasileiro que ouviu os gritos de Roberto e foi ao local, onde

[...] viu que Magalhães dava com um chicote de trança no preto Roberto e que este todo ensanguentado pedia a Magalhães que não lhe batesse mais. Disse mais que elle depoente pedira a Magalhães que não batesse mais no preto, Magalhães respondeu que naquella hora não attendia a ninguem. ${ }^{51}$

Várias testemunhas confirmaram a agressão com pau e chicote. Na versão de Roberto, Magalhães exigiu um ritual de submissão após o espancamento:

[...] depois [da surra], elle declarante levantou-se e Magalhães lhe perguntou si se sujeitava a continuar como seu camarada apezar de levar sovas de reio, ao que elle declarante 
Desrespeito e violência: fazendeiros de café e trabalhadores negros...

respondeu que sim, em vista de ver que o portão do quintal continuava feichado; então Magalhães o mandou asperamente que fosse tractar dos animais ao que elle obedeceu.

Magalhães explicou para testemunhas que "havia dado uma sóva no seu referido camarada, porque, tendo este [Magalhães] ordenado cortar capim para o seu cavallo, não o fez". ${ }^{52}$ Ao passo que testemunhas brasileiras e italianas relataram o evento de maneira relativamente objetiva, um português, empregado de comércio, deu um depoimento francamente favorável a Magalhães, enfatizando a desobediência de Roberto:

Antonio Pinto de Magalhães há dias contrariava-se com Roberto por não cumprir com suas obrigações, deixando por diversas vezes de tratar os animais na cocheira, como acontteceu no dia que Roberto foi espancado. ${ }^{53}$

Magalhães se enfureceu com a presunção de Roberto de controlar seu próprio tempo, trabalhando na hora que queria. Não existe nenhum outro indício de desrespeito ou desacato no processo além dessa falta de cumprir as tarefas exigidas e a presença de Roberto na venda. Roberto, de sua parte, disse a Magalhães que aceitava essa "correição", mas deixa claro na sua declaração que só disse isso porque não havia como fugir do espancamento. Depois de sair do quintal, denunciou Magalhães ao subdelegado. O significado do chicote não escapou ao promotor, único branco que se manifesta de maneira claramente indignada nos autos. Chamando o espancamento uma "scena de cannibalismo", escreve que

Antonio Bravo, assim procedendo, não se limitava em offender physicamente o seu camarada, mais do que isto, aviltava-o, por isso que, serviu-se de um relho, instrumento unicamente empregado pelo homem contra os animais inferiores a menos que elle o queria amesquinhar a individualidade do seu semelhante.

Anos 90, Porto Alegre, v. 12, n. 21/22, p.103-149, jan./dez. 2005 
Menos de um mês depois, Magalhães foi acusado de espancar com cabo de relho um marceneiro pardo suspeito de ter roubado uma besta. ${ }^{54}$

Em outro conflito sobre o trabalho, em 1892, Giuseppe Mirabelli, "lavrador" calabrês de 31 anos, esfaqueou sua cozinheira preta, segundo testemunhas, porque ela não preparara a comida, e o café dele estava frio. ${ }^{55} \mathrm{Na}$ sua declaração ao delegado, a cozinheira acresceu outro motivo pela fúria do patrão: ela o havia admoestado por tentar seduzir uma mulher casada (e aparente-

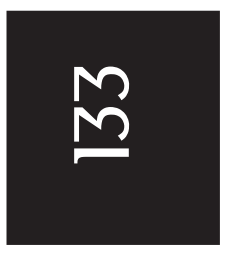
mente negra); ou seja, ela "não sabia seu lugar" e ousou dar conselhos a um branco.

Com o aumento no número de imigrantes que compraram fazendas ou se empregavam como administradores ou diretores de colonos, a violência desses imigrantes contra trabalhadores negros aparentemente se tornou mais comum. O maior fazendeiro estrangeiro do município era o médico russo Dr. Procópio Davidoff, que casara com a herdeira das terras (Truzzi, 2004, p.67). Em 1911, Dr. Davidoff repreendeu Theodoro, carroceiro negro, que descarregava café no lugar errado. Segundo uma testemunha italiana, Davidoff chamou o Theodoro de "negrinho atôa". Em resposta, Theodoro, na versão de uma testemunha brasileira, "começou a resmungar". Com isso Boris, o filho do fazendeiro, "lhe disse que não queria que ele respondesse mal ao seu pae e avançando para o lado de Theodoro deu-lhe dois tapas e disse-lhe eu risco vosse só cachorro". Além de dar os tapas, Boris feriu Theodoro com uma faca e multou-o (Medeiros, 2004, p.80-83).

Boris obviamente quis impor respeito ao negro, o que incluía este ouvir insultos sem responder. Era comum fazendeiros usarem a palavra "cachorro" para qualificar trabalhadores imigrantes atrevidos, assim deixando claro que os consideravam seres inferiores, mas parece que fazendeiros e administradores preferiam o insulto "negro" para os descendentes de escravos porque evocava o estigma 
Desrespeito e violência: fazendeiros de café e trabalhadores negros...

da escravidão de uma maneira que "cachorro" - usado com trabalhadores e subordinados em geral - não conseguia.

Em 1912, Giovanni de Rienzo, italiano, 50 anos, dono de uma pequena fazenda de café, deu pauladas em um trabalhador preto da mesma idade por sua impudência, quebrando seu braço e machucando suas costelas. ${ }^{56}$ Parece que o conflito se iniciou no dia anterior. Segundo Rienzo, "o seu camarada o preto José Martins, durante o dia todo em vez de trabalhar discutia e procurava questões com elle declarante o qual devida a sua muita paciência com elle não brigou". ${ }^{57} \mathrm{Um}$ colono brasileiro relatou que Rienzo discutiu com José a respeito do trabalho e que este abandonou o cafezal, voltando para sua casa na colônia da fazenda, e começou a xingar o patrão. ${ }^{58}$ Segundo trabalhadores italianos, brasileiros e portugueses que presenciaram os eventos no dia seguinte, Martins trouxera uma garrafa de cachaça ao cafezal. Quando Rienzo lhe disse que não devia beber durante o serviço, José respondeu. $\mathrm{Na}$ maioria dos relatos, retrucou: "não me amole." Em uma versão, também chamou Rienzo de ladrão; em outra, desafiou-o para uma briga. Em resposta, Rienzo vibrou-lhe duas ou três pancadas. Rienzo afirmou no inquérito que "depois de ter sido muito insultado por José perdeu a paciência e com um pedaço de pau deu nelle José duas pancadas". Quando interrogado pelo delegado, José não manifestou arrependimento por sua rebeldia. Quando admoestado por Rienzo a respeito da cachaça, retrucou, na sua versão:

[...] que aquilo não fazia mal e então João de Rienzo ficou zangado e disse muitos desaforas a elle declarante que por sua vez respondeu na mesma forma, que João de Rienzo lançando mão de um pau deu nelle declarante uma pancada dirigida a cabeça, que rebateu esta pancada levantando os braços e tendo recebido este digo, neste essa pancada, que em seguida João deu-lhe mais duas pancadas que lhe acertaram nas costas, que com a pancada recebida no braço este fraturou-se. 
Karl Monsma

Conforme o promotor, Rienzo tentou esconder seu crime, impedindo José de ir ao médico e de registrar a queixa com o delegado. Foi somente três dias depois que mandou José a um médico no povoado de Água Vermelha. Na sua declaração perante o juiz um mês depois, Rienzo foi franco sobre sua vontade de pôr José de volta no seu lugar: "Martins que havia tempos andava reinando começou a não trabalhar e por isso teve necessidade de educa-lo." Levou mais ou menos um mês para José se curar; depois voltou a trabalhar na fazenda de Rienzo, que foi absolvido pelo júri.

Durante a colheita de 1914, o colono negro Benedicto Barboza suspeitava que sua família fora discriminada pelo diretor de colonos, o português Antonio Dias Lopes, porque este lhe mandou colher em "uma rua de café pouco carregada". ${ }^{59}$ Benedicto reclamou com os outros trabalhadores, e depois com o diretor "pelo facto delle director, anda trocando as numerações das ruas de café, para proteger outros colonos" e disse que reclamaria ao administrador. ${ }^{60}$ Isso levou a uma troca de insultos entre os dois. A ofensa de Benedicto que o diretor lembrava melhor, e o único que reproduziu na sua declaração ao delegado, era "va embora d'aqui, seu portuguezinho". Pouco depois Benedicto, conforme testemunhas, gritou para sua mulher lhe trazer seu facão e Antonio tirou um revólver e deu dois tiros no negro. ${ }^{61}$ Ao tratar o diretor com o diminutivo, mandá-lo embora e chamar a atenção para sua nacionalidade, Benedicto questionava o direito de este estrangeiro mandar nele

Em junho de 1914, Antonio Colodro, espanhol e diretor de colonos, dirigia um grupo de colonos no conserto da estrada entre a fazenda Santa Elisa e a estação de trem mais próxima. Agenor de França, jovem colono preto, e um austríaco fizeram um intervalo para ir a uma venda tomar pinga. Quando voltaram, o diretor dispensou seus serviços, mandando-os voltar para a fazenda. Em resposta, segundo Antonio, "Agenor desobedecendo a elle depoente disse que ficava no trabalho porque elle depoente não mandava

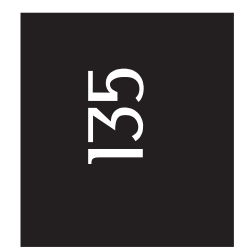


Desrespeito e violência: fazendeiros de café e trabalhadores negros...

nada, dizendo-lhe ainda palavras obcenas bastante injuriosas". ${ }^{62}$ $\mathrm{Na}$ versão de Agenor, quando o diretor o mandou embora, disse “então eu aqui não mando nada? É melhor vocês fazerem o que quizer; elle depoente replicou: você é um hespanholinho atôa, está cantando prosa" ${ }^{63}$ Segundo várias testemunhas, Agenor na realidade chamou o diretor de "hespanholinho de merda" ou "hespanholinho a toa de merda". Com isso o espanhol sacou um revólver e atirou no negro, deixando-o com um ferimento grave no braço.

Novamente, há o uso do diminutivo para rebaixar um diretor de colonos estrangeiro, e o diretor recorre imediatamente à violência física, e potencialmente letal, para sustentar sua autoridade contra a insolência de um negro. Do lado dos negros devia ter sido difícil acatar as ordens de estrangeiros, muitos dos quais haviam chegado poucos anos antes e tão pobres como eles. O contraste entre a atitude do austríaco e a de Agenor é instrutivo. Quando o austríaco voltou da venda, chegando um pouco antes de Agenor, e foi dispensado pelo diretor, ele simplesmente disse, na versão dele, "sim, senhor" e foi embora. ${ }^{64}$

Fazendeiros e administradores imigrantes também manifestavam tendência a desrespeitar as famílias e a vida privada dos negros. Em algum momento em 1893 ou início de 1894, o preto Miguel Raphael se empregou como camarada do empreiteiro português José Martins Marcellino. Martins também empregou a amásia de Miguel, Luisa, como cozinheira. Algum tempo depois, segundo a declaração de Miguel ao delegado,

José Martins despachou-o do serviço sem motivo algum, e recusou a que a companheira acompanhasse ao respondente, do que resultou uma discussão entre ambos, como obstinadamente insistisse na recusa elle respondente retirou-se da casa de seu dito patrão. ${ }^{65}$ 
Miguel foi trabalhar em uma fazenda vizinha. Fica evidente no processo que cozinheira não era a única função que Luisa desempenhava na casa de Martins. Depois de demitir Miguel, José Martins ainda lhe desferiu dois tiros de garrucha. Conforme Antonio, filho de José Martins,

[...] sabe por ouvir falar que seu pai José Martins há um ano mais ou menos, disparou tiro de arma de fogo contra Miguel, mas ignora a causa, entretanto suppõe que seja por

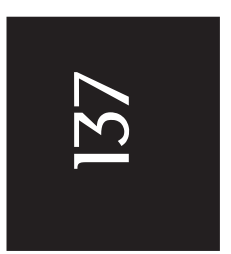
causa d'uma preta que estava em companhia de seu pai a qual era mulher ou amasia de Miguel. ${ }^{66}$

Um ano depois desses tiros, Miguel foi à casa de Martins quando este não estava e brigou com Luisa, que não quis acompanhá-lo. ${ }^{67}$ Os filhos de Martins, Manoel, 16, e Antonio, 18, alegaram que Miguel também desatinou a mãe e as irmãs deles. Chamados à casa, os irmãos mandaram Miguel embora, "e effectivamente este deo de retirar-se, mas sempre insultando a elle depoente e a seu mano e chamando-os que o acompanhassem". ${ }^{68}$ Com este desafio, os irmãos o perseguiram. Depois de segui-lo por um tempo, Manoel desfechou-lhe um ou dois tiros de garrucha, acertando-o nas costas. Várias testemunhas disseram que os irmãos também deram pauladas em Miguel. Depois disso, ainda continuaram perseguindo o negro por algum tempo.

Testemunhas não tinham dúvidas de que o conflito entre Miguel e José Martins era sobre quem ficaria com Luisa. Um "lavrador" brasileiro disse que

[...] ouvio do próprio filho de José Martins de nome Manoel Martins que havia este atirado no preto Miguel a mandado de seu referido pai por causa da preta Luisa que foi companheira de Miguel e que hora achava-se em companhia de José Martins. Sabe mais que o ano passado o dito José Martins 
Desrespeito e violência: fazendeiros de café e trabalhadores negros...

já dera um tiro no referido preto Miguel ainda por causa da mesma preta Luisa; [José Martins] é dado a valentão, já tendo espancado diversas pessoas no bairro onde móra. ${ }^{69}$

Embora pareça que Luisa realmente queria ficar com José Martins, este nunca tratou a decisão como unicamente dela. A família Martins Marcellino havia chegado a São Carlos, e possivelmente ao Brasil, somente dois anos antes, ao final de 1892 ou início de 1893, mas José Martins já agia com a prepotência de um escravocrata. Querendo a mulher de Miguel para si, simplesmente tocou-o da sua empreitada e espantou-o com tiros quando apareceu.

Em outubro de 1901, Savério Guzzi, italiano e administrador da Fazenda Morro Redondo, encontrou o liberto Mateus, 36, discutindo com outro trabalhador brasileiro (aparentemente branco), Manoel Novaes, porque este tentava proibir Mateus de visitar sua filha Luiza, de 15 anos. ${ }^{70}$ Conforme uma jovem testemunha brasileira, Guzzi disse a Mateus: "cale a bôca, senão você apanha; Matheus disse então: você é baixo para mandar me calar a bôca. Guzzi ouvindo isto, retirou-se foi na fazenda pegou em um chicóte e foi procurar Matheus". ${ }^{71}$ Achando Mateus perto do terreiro, Savério começou a chicoteá-lo. Então Mateus disse - segundo Luiza, que ouviu de outra mulher, "você não me bate, digo, bata mais, Savério" e lhe deu uma pancada no braço com um pau. ${ }^{72}$ Com isso Guzzi sacou uma pistola e atirou em Mateus, que caiu morto. $^{73}$

O significado do chicote para um ex-escravo dispensa comentários, e a rapidez com que Guzzi recorreu a este instrumento de castigo sugere que desprezava Mateus e queria lhe humilhar. Conforme Luiza, "Savério constantemente ralhava com Matheus e chegava mesmo a dar neste". Matar o liberto era uma reação natural e automática quando este desafiou o administrador italiano, recusando-se a se submeter à punição. 
O desprezo de fazendeiros ou administradores imigrantes por indivíduos negros específicos, ou a intolerância de negros em geral, também transparece em outros processos. Em 1902, uma portuguesa, amasiada com o fazendeiro brasileiro José Cardoso de Toledo França, deu pancadas em um preto porque ele estava, à noite, perto de casa da máquina de beneficiar café e ela presumia que ele fosse ladrão. Benedicto Machado, 19 anos, e seu pai eram colonos da fazenda, e Benedicto havia ido à casa da máquina para coletar algumas ervas que ali cresceram para tratar seu pai, que se achava doente. A fazenda sofreu vários furtos, e o fazendeiro havia pedido para um português, seu compadre Joaquim Pompeo da Silva, fiscalizar a área ao redor da casa. Quando este foi para a casa, percebeu um vulto.

Dirigiu-se a encontro do dito vulto e reconheceu que éra o acusado que tinha vindo ali em busca de umas hérvas para remédio de seo pae. O depoente aconselhou-o para que fosse embóra visto que tinha órdem de não deichar ninguem ali ficar, o acusado respondera que não éra ladrão e que aceitando o conselho do depoente ia se retirando e que n'esse acto Maria dos Anjos companheira de seu cumpadre José Cardoso de Toledo França perguntou ao depoente quem estava ali e sabendo que éra Benedicto disse ao depoente que não o deichasse ir imbóra sem que o levasse em presença do dono da caza. O acusado n'este acto ensultoua com algumas palavras. Maria dos Anjos exasperando-se com tal insulto aproximou-se do acusado e deu-lhe algumas pancadas que o depoente as rebateu. $\mathrm{O}$ depoente viu quando o acusado deu algumas pancadas tambem em Maria dos Anjos e rebateu-as igualmente. ${ }^{74}$

$\mathrm{Na}$ versão de Benedicto, Maria apareceu chamando-o de ladrão: 
Desrespeito e violência: fazendeiros de café e trabalhadores negros...

[...] n'esse momento aparece a Sra Maria dos Anjos disendo que o condusido éra o ladrão que por diversas vezes tinha roubado alguns objectos da fazenda, e que quando o condusido queria provar a sua inocencia foi-lhe vibrado uma bordoada por Maria dos Anjos e que repetiu mais duas bordoadas no condusido. O condusido exasperandose com aquella agressão deu em Maria dos Anjos uma bordoada com uma bengala que trasia. ${ }^{75}$

Joaquim levou Benedicto à presença do fazendeiro, que estava em uma venda. Nesse trajeto, seguindo Benedicto, "a amasia deste que se chama Maria e que é de nacionalidade portugueza, descompunha elle declarante de nomes indecorósos e de ladrão". ${ }^{76}$ Ele ainda disse que um dos dois administradores, espanhol e italiano, lhe deu uma pancada com cabo de relho quando o trancavam na tulha para esperar ser conduzido ao subdelegado da vila de Ibaté, não especificando qual dos dois o agrediu.

Se Benedicto tivesse sido branco, Maria provavelmente não o teria acusado tão rapidamente de ser ladrão. Parece que os insultos que Benedicto proferiu contra Maria, nas versões de Joaquim Pompeo e de Maria, respondiam a essa acusação. Se a declaração de Benedicto está certa, um dos administradores estrangeiros ainda aproveitou a ocasião para bater em um preto.

Em fevereiro de 1913, Luigi Calegari, fazendeiro italiano, esbordoou um preto, ex-empregado dele, de 67 anos, do lado de fora de uma venda perto da estação da Babylônia porque o preto, Ignácio Justino, convidara-o para tomar algo e se ofendera com sua recusa. ${ }^{78} \mathrm{O}$ convite parecia particularmente despudorado, porque Calegari havia demitido Ignácio um par de anos antes e suspeitava que este, para se vingar, tentara incendiar sua casa. Para piorar a situação, Ignácio bebia com um trabalhador atual de Calegari, que faltava ao serviço. Um empregado italiano da venda descreveu a discussão que precedeu as pancadas:

Anos 90, Porto Alegre, v. 12, n. 21/22, p.103-149, jan./dez. 2005 
Karl Monsma

[...] chegou Luiz Calegari que vendo seu camarada de nome Joaquim Albino em companhia de Ignácio Justino e Francisco Leite, mostrou-se admirado por vê-lo aquela hora fora do serviço quando mesmo Albino se havia comprometido a fazer três quartos do dia, que dali a instante Ignácio Justino convidou Calegari para tomar alguma couza, ao que não acedeu Calegaro dizendo que elle é que podia pagar porque dispunha de mais recurso do que Ignácio Justino, por essa razão travou-se uma discussão entre os dois e durante a qual Calegari chamou Ignácio de incendiário acusando-o de haver a tempos ter posto fogo na casa em que Calegari residia com sua família, que assim discutindo os dois foram para o lado de fora do armazém. ${ }^{79}$

Os golpes claramente não foram defensivos. Depois Calegari afirmou que Ignácio o atacara com uma navalha, mas nenhuma das testemunhas corroborou isso, dizendo ou que Ignácio estava sem arma, ou que não teve tempo para sacar sua navalha. As circunstâncias sugerem que, em vez de se defender, Calegari tentava dar uma lição a Ignácio e rebaixá-lo. Outros fregueses da venda, presumivelmente brancos, parecem ter apreciado a cena: uma testemunha disse que ouviu um grupo gritando "bata, bata". 80

\section{Conclusão}

Após o fim da escravidão, os descendentes de escravos continuavam estigmatizados e, com o passar do tempo, o estigma do cativeiro se transmutou em estigma de cor, agora aplicado a todos os negros, com certa atenuação no caso dos mulatos. O habitus dos escravocratas, e de muitos outros brancos acostumados a lidar com escravos na vida cotidiana, não mudou com a Lei Áurea. Sem precisar refletir ou ler a ideologia do racismo científico, eles entendiam que os negros eram naturalmente inferiores, nascidos 
Desrespeito e violência: fazendeiros de café e trabalhadores negros...

para servir, que eram permanentemente dependentes e infantis, sem o direito a uma vida privada fora do controle do senhor.

Mas o racismo após a abolição não era uma simples continuação de velhas disposições e esquemas de percepção e ação escravistas. O período de revolta e fugas em massa dos anos 80 intensificou o desprezo racial dos brancos. Em função dessa rebeldia, muitos "pretos" ignorantes e infantis, na visão da elite, viraram "negros" traiçoeiros e perversos (Schwarcz, 1987). Havia um elemento de revanchismo na violência de fazendeiros e administradores contra negros após a abolição, e agora eles podiam matar negros sem se preocupar com a destruição da propriedade que era o escravo.

Além disso, é inegável que alguns libertos agiam de forma que confirmava, para quem está predisposto a enxergar somente um lado da realidade, que os negros em geral eram irresponsáveis e corrompidos. Embora a embriaguez fosse comum em todos os grupos étnicos e raciais, a presença de certo número de negros alcoólatras confirmava a degeneração da raça; a resistência de outros ao trabalho supervisionado e sua busca por autonomia e controle do ritmo de trabalho confirmavam que não trabalhariam bem sem a ameaça de castigos físicos.

Contudo, nada disso explicaria a hipersensibilidade dos fazendeiros e seus agentes ao desrespeito e à desobediência de negros sem a presença de outro fator: estes seres "inferiores" agora reivindicavam o respeito e a igualdade com brancos. Negros que pareciam não saber seu lugar recusavam-se a mostrar deferência e ultrapassavam os limites "naturais" na interação com seus superiores, e geravam profunda irritação.

Os imigrantes em posições de autoridade nas fazendas evidenciavam as mesmas tendências racistas que seus pares brasileiros. A tendência nítida para conflitos a respeito do trabalho entre trabalhadores negros e fazendeiros, administradores e diretores de colonos imigrantes sugere que, de maneira geral, os negros resistiam

Anos 90, Porto Alegre, v. 12, n. 21/22, p.103-149, jan./dez. 2005 
mais a se submeter a imigrantes que a brasileiros brancos e, possivelmente, que estes imigrantes em posições de autoridade eram ainda mais sensíveis que seus congêneres brasileiros aos desacatos dos negros. Como é que imigrantes sem nenhuma experiência da sociedade escravista internalizavam as mesmas disposições dos velhos escravocratas? Parece que, com pouco tempo no Brasil, eles percebiam as condições de vida dos negros como evidência da sua inferioridade. Ademais, a maior parte dos imigrantes, sobretudo os que chegaram pobres, tentava se distinguir dos negros

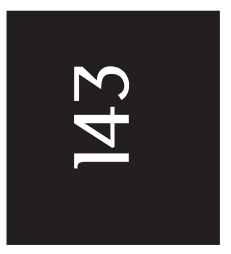
porque receava ser tratada como estes (Monsma, 2006; Monsma; Ferreira; Silva, 2004, p.49-60). Parece que muitos dos imigrantes que compraram pequenas fazendas ou ascenderam a posições de autoridade nas fazendas de brasileiros ainda sentiam a necessidade de demonstrar sua superioridade aos negros, o que intensificava suas reações à desobediência e ao desrespeito destes.

Disrespect and violence: coffee farmers and black workers in the Western São Paulo, 1887-1914

Abstract. The article examines relations between coffee planters and black workers after the abolition of slavery in the municipality of São Carlos, in Western São Paulo, focusing primarily on violent conflicts registered in criminal court records. Afro-Brazilians demanded respect and dignity, and struggled to defend their right to privacy; planters, who still resented slave rebelliousness during the last years before abolition, responded with irritation at any sign of disrespect by blacks, rapidly resorting to violence to degrade and humiliate them, a tendency less evident in planter interaction with immigrant workers. Immigrants who bought coffee plantations or assumed positions of authority on the plantations soon internalized the same racial dispositions exhibited by their Brazilian counterparts.

Keywords: Racial violence. Freedmen and women. Coffee planters.

Post-Abolition period. Western São Paulo, Brazil. 
Desrespeito e violência: fazendeiros de café e trabalhadores negros...

\section{Notas}

${ }^{1}$ Agradeço a ajuda da presidente e dos funcionários da Fundação Pró-Memória de São Carlos (doravante FPM).

${ }^{2}$ FPM, cx. 334, n. 2656, 1887, Cosme, Crispim, Felício e João Criolo.

${ }^{3}$ É possível que quebrar os galhos fosse uma forma de resistência a um ritmo de trabalho sentido como desmedido, o que significaria que o insulto do administrador era uma tentativa de coibir tal resistência. Entretanto, o ponto mais importante aqui é que o estopim da violência foi o insulto, não o ritmo de trabalho em si.

${ }^{4}$ Cf. Mattos (1998). Parece que os escravos novos também eram mais propensos a fugir (Antonio Carlos de Arruda Botelho a sua mulher, Anna Carolina de Mello Oliveira, 9/11/1876, cf. Botelho (2000. p. 38-39).

${ }^{5}$ Sobre o processo de fechamento social de um grupo estabelecido e a estigmatização dos recém chegados (os outsiders), ver Elias (1994). A referência clássica sobre a estigmatização e suas conseqüências para a identidade individual é Goffman (1963). ${ }^{6}$ Sobre São Paulo, ver Wissenbach (1998) e, sobre Porto Alegre, ver Moreira (2003). ${ }^{7}$ Muitos estudiosos atuais, inclusive vários dos citados acima, apontariam que Patterson não reconhece a capacidade que os escravos evidenciaram de construir comunidades e conquistar o respeito de seus pares ainda durante a vigência da escravatura. Mesmo se os livres os tratassem como indignos, havia noções de honra que norteavam as relações entre escravos (cf. Graham, 1998). Contudo, o ponto de Patterson sobre os efeitos psicológicos da sujeição e da desonra (com relação aos livres) continua válido.

${ }^{8}$ Os avanços espetaculares dos últimos anos nos estudos da escravidão brasileira contrastam com a falta de atenção à sorte dos negros após o treze de maio. Há exceções. Andrews (1991) é um dos poucos livros dedicados ao tema; partes de Alaniz (1997) e de Xavier (1996). Scott (1994, p. 70-102) compara a situação de libertos após a abolição final nas regiões açucareiras do Nordeste brasileiro, de Cuba e do Estado de Louisiana, EUA. Maciel (1997) fez um levantamento de artigos de jornais sobre negros após a abolição em Campinas. Alguns que estudam a Primeira República diluem as especificidades da experiência afro-brasileira na categoria mais ampla dos pobres, ou das classes populares (Carvalho, 1998; Pinto, 1994). Outros, sobretudo os que pesquisam autos penais, que fornecem mais informações sobre a vida cotidiana dos pobres, abordam interações entre brancos e negros ou a discriminação na Justiça, mas focalizam quase exclusivamente a vida nos grandes centros urbanos (Chalhoub, 1986; Esteves, 1989; Fausto, 2001; Ribeiro, 1995).

${ }^{9}$ FPM cx. 293, n. 64, 1894, depoimento de Severo Francisco da Silva ao delegado. ${ }^{10}$ FPM cx. 293, n. 64, 1894, depoimento de Severo Francisco da Silva ao delegado.

${ }^{11}$ Depoimento de Firmino Augusto dos Santos ao delegado.

Anos 90, Porto Alegre, v. 12, n. 21/22, p.103-149, jan./dez. 2005 
${ }^{12}$ A pesquisa de Dominique Vidal (2003) mostra que, até hoje, muitos brasileiros pobres continuam reivindicando o respeito como o direito mais fundamental da cidadania.

${ }^{13}$ 08/04/1886 e 01/02/1888 (Botelho, 2000, p. 46, 49).

${ }^{14} 28 / 10 / 1888$ e 05/11/1888 (Botelho, 2000, p. 54, 56).

${ }^{15}$ Livro de contas, 1890, arquivo da Fazenda Pinhal.

${ }^{16}$ Os camaradas que trabalhavam na colheita recebiam pelo número de balaios que enchiam, o que permitia uma fiscalização menos constante.

${ }^{17} 27 / 10 / 189$ (Botelho, 2000, p. 99-100).

${ }^{18} 12 / 05 / 1890$ e 22/10/1891 (Botelho, 2000, p. 68, 98).

${ }^{19}$ 24/01/1898 (Botelho, 2000, p. 139).

${ }^{20}$ Relatório apresentado ao Illmo e Ex Snr. Dr Pedro Vicente de Azevedo, presidente da Provincia de São Paulo, pelo desembargador Ernesto Julio Bandeira de Mello, chefe de Polícia no dia 7 de janeiro de 1889. São Paulo, 1889.

${ }^{21}$ FPM, cx. 263, n. 1560, 1898.

${ }^{22}$ FPM, cx. 265, n. 454, 1894, José Francisco.

${ }^{23}$ Depoimento de Cesário Terra ao delegado.

${ }^{24}$ FPM, cx. 262, sem número, 1894, Luiz Leme, José Leme, Fernando Leme, Domingos de Credico, Domingos Paiaroni, Giuzeppe Paiaroni.

${ }^{25}$ FPM, cx. 292, n. 3, declaração ao delegado.

${ }^{26}$ Depoimentos de Manoel Domingos e Jeronymo Coppette ao delegado.

${ }^{27}$ FPM, cx. 193, sem número, depoimento de Sebastiana Carneira ao delegado.

${ }^{28}$ Depoimento de João Baptista Fernandes ao delegado.

${ }^{29}$ Depoimento de Paulino Antonio Roza ao delegado.

${ }^{30}$ FPM, cx. 291, n. 57, depoimento ao delegado.

${ }^{31}$ Depoimento ao delegado.

${ }^{32}$ FPM, cx. 283, n. 254, 1893, depoimento de João Felix de Oliveira ao delegado.

${ }^{33}$ FPM, cx. 260, n. 2179, depoimento de Joaquim Antonio da Silva ao juiz.

${ }^{34}$ Depoimento de Sebastião Pinto de Sampaio ao juiz.

${ }^{35}$ Depoimento de Mariano Martins ao juiz.

${ }^{36}$ FPM, cx. 199, n. 118, declaração ao juiz.

${ }^{37}$ FPM, cx. 199, n. 118, declaração ao juiz.

${ }^{38}$ Declaração ao delegado.

${ }^{39}$ Depoimento de Benedicto Baptista ao delegado.

${ }^{40}$ Depoimentos de Rosa Accetto ao delegado e ao juiz.

${ }^{41}$ Depoimento de João da Silva ao delegado.

${ }^{42}$ FPM, cx. 333, n. 1199.

${ }^{43}$ FPM, cx. 210, sem número, 1901, Manoel Candido e Agostinho da Cunha Caldeira, telegrama (incluso no processo) de Leopoldo Guimarães ao chefe de Polícia de São Paulo; depoimento de Leopoldo Guimarães ao juiz.

Anos 90, Porto Alegre, v. 12, n. 21/22, p.103-149, jan./dez. 2005 
Desrespeito e violência: fazendeiros de café e trabalhadores negros...

${ }^{44}$ FPM, cx. 310, n. 438, declaração ao delegado. Ezequiel também alegou que José tentou lhe dar uma cacetada, mas os companheiros de José negaram isso.

${ }^{45}$ FPM, cx. 257, n. 25, 1895, Alberto José de Castro.

${ }^{46}$ Depoimento de Caetano Vavolisso ao delegado.

${ }^{47}$ Depoimento de João Henrique do Valle ao delegado.

${ }^{48}$ Depoimentos de Domingos Vistro e Rubino Natali.

${ }^{49}$ FPM, Censo municipal de 1907.

${ }^{50}$ FPM, cx. 308, sem número, 1897, Antonio Pinto de Magalhães.

${ }^{51}$ Depoimento ao delegado.

${ }^{52}$ Depoimento de Pedro de Almeida Silveira ao juiz.

${ }^{53}$ Depoimento de Antonio Rebello dos Santos ao delegado.

${ }^{54}$ FPM, cx. 308, sem número, 1897, Antonio Pinto de Magalhães.

${ }^{55}$ FPM, Criminais, cx. 214, n. 138, 1892, Giuseppe Mirabelli.

${ }^{56}$ FPM, Criminais, cx. 310, n. 435, 1912, João de Rienzo.

${ }^{57}$ Declaração ao delegado.

${ }^{58}$ Depoimento de Sebastião Sabino ao delegado.

${ }^{59}$ FPM, cx. 243, n. 507, depoimento de Augusto Baldano ao delegado.

${ }^{60}$ Declaração de Benedicto Barboza ao delegado.

${ }^{61}$ Benedicto ficou com ferimentos leves.

${ }^{62}$ FPM, cx. 175, n. 443, declaração ao subdelegado de Santa Eudóxia.

${ }^{63}$ Declaração ao subdelegado.

${ }^{64}$ Depoimento de Luiz Brumatti ao subdelegado.

${ }^{65}$ FPM, cx. 211, n. 206, 1895.

${ }^{66}$ Declaração de Antonio Martins Marcellino ao delegado.

${ }^{67}$ Depoimento de Luisa Margarida ao delegado.

${ }^{68}$ Declaração de Antonio ao delegado.

${ }^{69}$ Depoimento de Francisco Braz Machado ao delegado.

${ }^{70}$ FPM, Criminais, cx. 464, sem número, 1901, Savério Guzzi.

${ }^{71}$ Declaração de Ramiro de Mattos Terra ao delegado.

${ }^{72}$ Declaração ao juiz.

${ }^{73}$ Savério Guzzi fugiu com um cavalo da fazenda e nunca foi encontrado pelas autoridades.

${ }^{74}$ FPM, cx. 208, n. 46, depoimento de Joaquim Pompeo da Silva ao subdelegado de Ibaté.

${ }^{75}$ Declaração ao subdelegado de Ibaté.

${ }^{76}$ Declaração ao delegado.

${ }^{77}$ Declaração ao delegado.

${ }^{78}$ FPM, Criminais, cx. 276, n. 6432, 1913, Luigi Calegari.

${ }^{79}$ Depoimento de Agostinho Chianelli ao delegado.

${ }^{80}$ Depoimento de José Victorino ao delegado.

Anos 90, Porto Alegre, v. 12, n. 21/22, p.103-149, jan./dez. 2005 


\section{Karl Monsma}

\section{Referências}

ALANIZ, Anna Gicelle García. Ingênuos e libertos; estratégias de sobrevivência familiar em épocas de transição, 1871-1895. Campinas: CMU/UNICAMP, 1997.

ANDREWS, George Reid. Blacks and whites in São Paulo, Brazil, 1888-1988. Madison: University of Wisconsin Press, 1991.

AZEVEDO, Celia Maria Marinho de. Onda negra medo branco: o negro no imaginário das elites; século XIX. Rio de Janeiro: Paz e Terra, 1987.

BOTELHO, Antonio Carlos de Arruda. Naninha, aceitai as minhas saudades; cartas

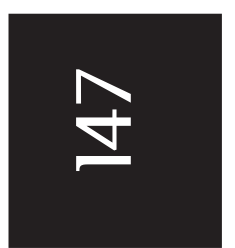
do Conde do Pinhal para Anna Carolina, sua esposa. São Carlos: EdUFSCar, 2000 .

BOURDIEU, Pierre. Méditations pascaliennes. 2. ed. Paris: Éditions du Seuil, 2003.

CARVALHO, José Murilo de. Os bestializados; o Rio de Janeiro e a República que não foi. São Paulo: Companhia das Letras, 1987.

CHALHOUB, Sidney. Trabalho, lar e botequim: o cotidiano dos trabalhadores no Rio de Janeiro da Belle Époque. São Paulo: Editora Brasiliense, 1986.

Visões da liberdade; uma história das últimas décadas da escravidão na Corte. São Paulo: Companhia das Letras, 1990.

COSTA, Emília Viotti da. Da senzala à colônia. 3. ed. São Paulo: UNESP, 1998.

ELIAS, Norbert; SCOTSON, John L. The established and the outsiders; a sociological enquiry into community problems. 2. ed. London: Sage, 1994.

ESTEVES, Martha de Abreu. Meninas perdidas; os populares e o cotidiano do amor no Rio de Janeiro da Belle Époque. Rio de Janeiro: Paz e Terra, 1989.

FAUSTO, Boris. Crime e cotidiano; a criminalidade em São Paulo (1880-1924). 2. ed. São Paulo: EDUSP, 2001.

GOFFMAN, Erving. Stigma; notes on the management of spoiled identity. Englewood Cliffs, N.J.: Prentice-Hall, 1963.

GRAHAM, Sandra Lauderdale. Honor among slaves. In: JOHNSON, Lyman L.; LIPSETT-RIVERA, Sonya (Org.). The faces of honor, sex, shame and violence in colonial Latin America. Albuquerque: University of New Mexico Press, 1998.

MACHADO, Maria Helena Pereira Toledo. Crime e escravidão; trabalho, luta e resistência nas lavouras paulistas, 1830-1888. São Paulo: Brasiliense, 1987.

Anos 90, Porto Alegre, v. 12, n. 21/22, p.103-149, jan./dez. 2005 
Desrespeito e violência: fazendeiros de café e trabalhadores negros...

MACHADO, Maria Helena. O plano e o pânico; os movimentos sociais na década da abolição. Rio de Janeiro; São Paulo: Editora UFRJ; EDUSP, 1994.

MACIEL, Cleber da Silva. Discriminações raciais; negros em Campinas (18881926). 2. ed. Campinas: Centro da Memória da UNICAMP, 1997.

MALIK, Kenan. The meaning of race; race, history and culture in western society. New York: New York University Press, 1996.

MARSHALL, T. H. Citizenship and social class. In: MARSHALL, T. H. Class, citizenship and social development. Garden City, NY: Doubleday, 1964.

MATTOS, Hebe Maria. Das cores do silêncio; os significados da liberdade no Sudeste escravista - Brasil, século XIX. Rio de Janeiro: Nova Fronteira, 1998.

MEDEIROS, Simone. Resistência e rebeldia nas fazendas de café de São Carlos-1888 a 1914. Dissertação (Mestrado em Ciências Sociais) - Universidade Federal de São Carlos, São Carlos, 2004.

MONSMA, Karl. Symbolic conflicts, deadly consequences: fights between Italians and blacks in western São Paulo, 1888-1914. Journal of Social History, summer 2006. No prelo.

MONSMA, Karl; FERREIRA, Lania Stefanoni; SILVA, Virgínia Ferreira da. Imigração e violência racial: italianos e negros no Oeste Paulista, 1888-1914. Impulso: Revista de Ciências Sociais e Humanas, v. 15, n. 37, p. 49-60, maio/ago. 2004.

MONSMA, Karl; MEDEIROS, Simone. Classe, etnia e violência nas fazendas de café do Oeste paulista, 1888-1914. In: BRUMER, Anita; Piñeiro, Diego (Org.). Agricultura latino-americana; novos arranjos e velhas questões. Porto Alegre: Editora da UFRGS, 2005.

MOREIRA, Paulo Roberto Staudt. Os cativos e os homens de bem; experiências negras no espaço urbano. Porto Alegre: EST, 2003.

NAXARA, Márcia Regina Capelari. Estrangeiro em sua própria terra: representações do brasileiro, 1870/1920. São Paulo: Annablume, 1998.

PATTERSON, Orlando. Slavery and social death; a comparative study. Cambridge, Mass.: Harvard University Press, 1982.

PINTO, Maria Inez Machado Borges. Cotidiano e sobrevivência; a vida do trabalhador pobre na cidade de São Paulo (1890-1914). São Paulo: Edusp, 1994.

RIBEIRO, Carlos Antonio. Cor e criminalidade; estudo e análise da justiça no Rio de Janeiro (1900-1930). Rio de Janeiro: Editora UFRJ, 1995.

Anos 90, Porto Alegre, v. 12, n. 21/22, p.103-149, jan./dez. 2005 


\section{Karl Monsma}

SCOTT, James C. Domination and the arts of resistance; hidden transcripts. New Haven, Conn.: Yale University Press, 1990.

SCOTT, Rebecca J. Defining de boundaries of freedom in the world of cane: Cuba, Brazil and Louisiana after emancipation. The American Historical Review, v. 99, n. 1, p. 70-102, Feb. 1994.

SLENES, Robert W. Na senzala, uma flor, esperanças e recordações na formação da família escrava - Brasil Sudeste, século XIX. Rio de Janeiro: Nova Fronteira, 1999.

SCHWARCZ, Lilia Moritz. Retrato em branco e negro; jornais, escravos e cidadãos em São Paulo no final do século XIX. São Paulo: Companhia das Letras, 1987.

TRUZZI, Oswaldo M. S. Café e indústria; São Carlos 1850-1950. 2. ed. São Carlos: EDUFSCar, 2000.

(Org.). Fontes estatístico-nominativas da propriedade rural em São Carlos. São Carlos: EDUFSCar, 2004.

VIDAL, Dominique. A linguagem do respeito. a experiência brasileira e o sentido da cidadania nos democracias modernas. Dados, v. 46, n. 2, p. 265-87, 2003.

XAVIER, Regina Célia Lima. A conquista da liberdade; libertos em Campinas na segunda metade do século XIX. Campinas: CMU/UNICAMP, 1996.

WISSENBACH, Maria Cristina Cortez. Sonhos africanos, vivências ladinas; escravos e forros em São Paulo (1850-1880). São Paulo: Hucitec, 1998.

Recebido em 25/05/2005.

Aprovado em 31/07/2005. 